\title{
Sequestration of defensive toxins by tetrapod vertebrates: contributions in memory of John W. Daly
}

\author{
Alan H. Savitzky $\cdot$ Ralph A. Saporito
}

Received: 22 May 2012/ Accepted: 13 July 2012 / Published online: 2 August 2012

(C) Springer Basel AG 2012
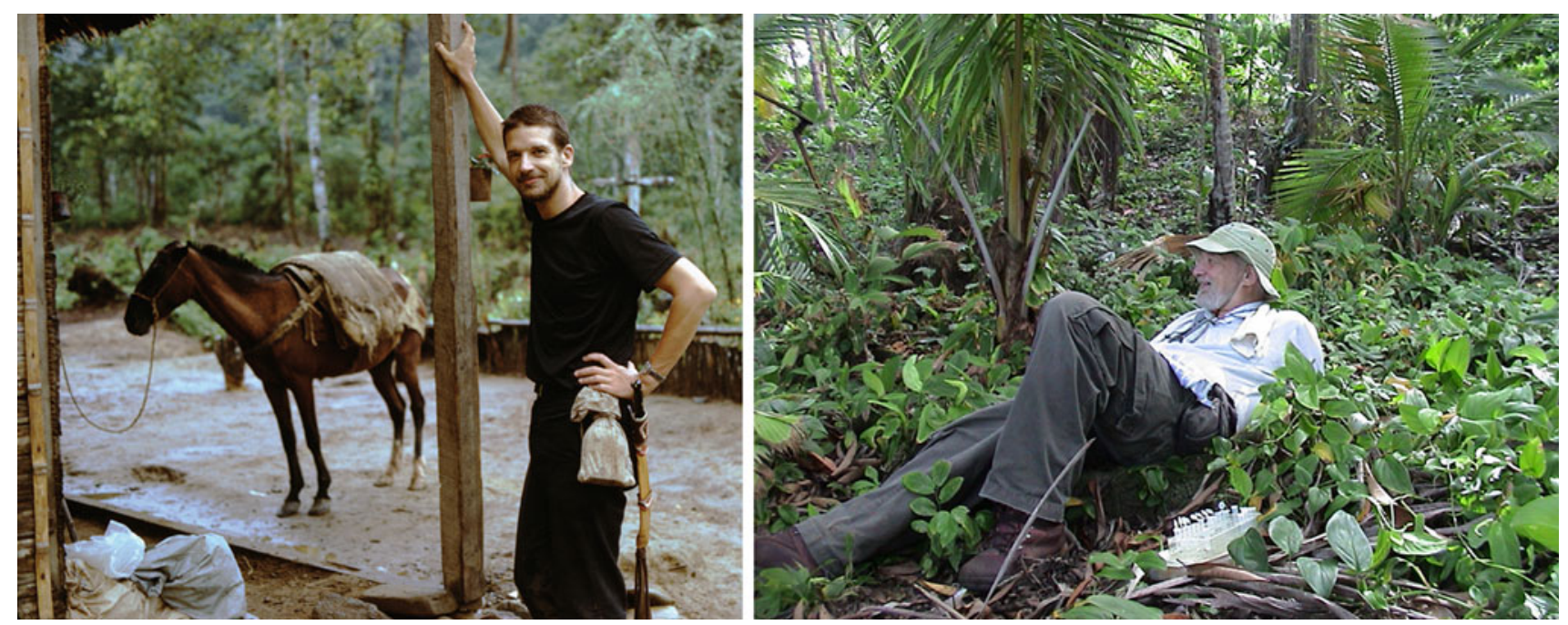

John W. Daly in the field in Colombia, 1970 (left from Myers 2009, courtesy of Charles W. Myers and Robert W. Hansen) and Panama, 2003 (right courtesy of Maureen A. Donnelly)

\section{Dedication}

By the early 1990s John W. Daly, of the National Institutes of Health, had been collecting and cataloguing toxins from the skins of frogs for about 30 years, on the assumption that the enormous variety of alkaloid toxins (by then

\footnotetext{
A. H. Savitzky $(\square)$

Department of Biology, Utah State University, Logan, UT 84322-5305, USA

e-mail: savitzky@usu.edu

\section{R. A. Saporito}

Department of Biology, John Carroll University, University Heights, OH 44118, USA

e-mail: rsaporito@jcu.edu
}

numbering in the hundreds) were synthesized by the frogs themselves (Daly 1998). However, he had begun to detect patterns that suggested the toxins might have a dietary origin, including temporal variation in toxin profiles within a population, similarity of toxins among frogs of four distantly related families (and even in a bird), the absence of alkaloids in captive-bred frogs, and the discovery of some identical compounds in a variety of small arthropods (Saporito et al. 2009). In a series of experiments in the mid1990s, Daly and his collaborators demonstrated that captive-reared and nontoxic frogs of the genus Dendrobates could acquire toxins from prey that had been dusted with alkaloids in the lab (Daly et al. 1994b). Furthermore, captive-reared frogs would, if housed with access to wild arthropods as prey, acquire alkaloid toxins (Daly et al. 
1994a). With these experiments, Daly not only demonstrated that the toxic alkaloids of dendrobatid frogs have a dietary origin, but he also documented for the first time among any terrestrial vertebrates the sequestration of defensive toxins from an environmental source (Saporito et al. 2009). Subsequent studies have not only confirmed and extended those findings with regard to poison frogs (Daly et al. 1997; Smith et al. 2002), but also led to the discovery of sequestered toxins in several other lineages of tetrapod vertebrates.

John received his B.S. in Biochemistry from Oregon State College in 1954 and his M.A. in Organic Chemistry in 1955, before moving to Stanford University to pursue his Ph.D. in Organic Chemistry (Garraffo 2009; Fitch and Bewley 2010). He completed his doctoral degree in 1958 and joined the Laboratory of Chemistry at the National Institutes of Health as a postdoctoral researcher, under Bernhard Witkop, the same year (Daly 1998). He became a permanent member of the scientific staff at NIH 2 years later. John rose to become the founding chief of the Laboratory of Bioorganic Chemistry at the National Institute of Diabetes and Digestive and Kidney Diseases (NIDDK) in 1978, a position he held until assuming the title of Scientist Emeritus upon his official retirement in 2003 (Garraffo 2009).

John was far more than an organic chemist, however. His training in pharmacology allowed him to address the physiological activity of many of the molecules he identified, while his interest in the frogs themselves led him to an interest in the evolutionary significance of amphibian toxins. His extraordinary collaboration with herpetologist Charles W. Myers, over more than 30 years, took them both to remote field sites across much of Latin America (Myers 2009). John also visited Madagascar, Australia, and Thailand in the pursuit of toxic frogs, supplementing his investigations into their chemistry with an expanding interest in amphibian biology in general. The author of over 600 publications and recipient of numerous awards, John was elected to membership in the National Academy of Sciences in 1997 (Myers 2009). Even as a Scientist Emeritus, he remained very active, continuing to address new avenues of research. In his last year of life, John was still pursuing field research in the tropics, in a professional career that spanned fully half a century.

On 21 August 2008, a symposium was held at the Sixth World Congress of Herpetology in Manaus, Brazil to discuss the sequestration of defensive toxins in diverse groups of amphibians and reptiles. John had been among the first individuals invited to speak and ultimately had agreed to co-author a contribution with a number of his longtime collaborators and recent colleagues. As preparations for the World Congress were underway, John learned of his rapidly progressing illness, and he died on 5 March 2008, of pancreatic cancer, less than 6 months before the symposium was held.

John's work on poison frogs remains the single largest body of research on sequestered toxins in any vertebrates and has served as an example to those of us interested in sequestered defensive toxins. Progress in this field has continued to accelerate in the period since the World Congress in Brazil, and recent developments are highlighted in this special issue. Among the authors are many of John's friends and colleagues, and we are honored to dedicate these published contributions to his memory.

\section{References}

Daly JW (1998) Thirty years of discovering arthropod alkaloids in amphibian skin. J Nat Prod 61:162-172

Daly JW, Garraffo HM, Spande TF, Jaramillo C, Rand AS (1994a) Dietary source for skin alkaloids of poison frogs (Dendrobatidae)? J Chem Ecol 20:943-955

Daly JW, Secunda SI, Garraffo HM, Spande TF, Wisnieski A, Cover JF Jr (1994b) An uptake system for dietary alkaloids in poison frogs (Dendrobatidae). Toxicon 32:657-663

Daly JW, Garraffo HM, Hall GSE, Cover JF Jr (1997) Absence of skin alkaloids in captive-raised Madagascan mantelline frogs (Mantella) and sequestration of dietary alkaloids. Toxicon 35:1131-1135

Fitch RW, Bewley CA (2010) Editorial: John W. Daly (1933-2008). J Nat Prod 73:299-300

Garraffo HM (2009) John William Daly, 1933-2008. Cell Mol Neurobiol 29:439-440

Myers CW (2009) Memories of John William Daly (1933-2008): a biographical sketch and herpetological bibliography. Herpetol Rev 40:53-65

Saporito RA, Spande TF, Garraffo HM, Donnelly MA (2009) Arthropod alkaloids in poison frogs: a review of the 'dietary hypothesis'. Heterocycles 79:277-297

Smith BP, Tyler MJ, Kaneko T, Garraffo HM, Spande TF, Daly JW (2002) Evidence for biosynthesis of pseudophrynamine alkaloids by an Australian myobatrachid frog (Pseudophryne) and for sequestration of dietary pumiliotoxins. J Nat Prod 65:439-447 